Original Article

\title{
FLOWERING, FORAGE VALUE, AND INSECT POLLINATION IN BORAGE (BORAGO OFFICINALIS L.) CULTIVATED IN SE POLAND
}

\author{
Ernest Stawiarz \\ Anna Wróblewska \\ Marzena Masierowska* \\ Dagmara Sadowska \\ Department of Botany and Plant Physiology, University of Life Sciences in Lublin, \\ Poland \\ *corresponding author: mIm25@up.lublin.pl \\ Received: 05 August 2019; accepted: 23 December 2019
}

\begin{abstract}
The three-year study on borage was conducted in Lublin, SE Poland. The aims were to investigate the flowering pattern and abundance, and the attractiveness (in terms of nectar and pollen production) for flower-visiting insects, mainly bees. Insect visitation and the effect of pollinators on fruit set and seed set were assessed as well. Flowering of borage started in the latter half of June and lasted eight weeks. The mean number of flowers $\cdot \mathrm{m}^{-2}$ of the crop was $\mathbf{4 5 7 0}$ per season. A borage flower produced on average 4.0 $\mathrm{mg}$ of nectar with a mean sugar concentration of $31.5 \%$. The mean total sugar amount secreted in nectar was $1.2 \mathrm{mg}$. The pollen amount $\cdot$ flower $^{-1}$ was $1.1 \mathrm{mg}$. A borage plant can supply insects with $1.1 \mathrm{~g}$ of nectar sugars and $1.1 \mathrm{~g}$ of pollen. The estimated nectar sugar yield and pollen yield per $1 \mathrm{~m}^{2}$ of the crop were similar, i.e. $5.2 \mathrm{~g}$. Bees accounted for $73.0 \%$ of all insect visits to the borage flowers. The presence of insect pollinators increased the fruit set by $43.3 \%$ and seed set by $26.8 \%$.
\end{abstract}

Keywords: bee pasture, flowering pattern, nectar production, pollen production and morphology

\section{INTRODUCTION}

Borage (Borago officinalis L.), Boraginaceae, is an annual species native to the Mediterranean region. It has been naturalized in Central, Eastern, and Western Europe and North America (Gupta \& Singh, 2010; Pieszak, Mikołajczak, \& Manikowska, 2012). In Poland, borage is a rare plant, cultivated mainly in home gardens but sometimes treated as a weed (Szafer, Kulczyński, \& Pawłowski, 1988; Trzaskowska, 2013). It is not grown in large areas of the country (Suchorska \& Osińska, 1997).

Borage has a rosette of basal leaves and a main stem, 60-100 cm in height, which branches into several axillary stems. Its actinomorphic flowers have five sepals and the same number of petals and stamens (Fig. 1a), and are gathered in scorpioid cymose inflorescences. The bases of the petals and stamens are fused with white throat scales, creating a reservoir for nectar. The pistil has a four-loculed ovary (Fig. 1bc). At the bud stage, the petals are pink, but later their colour changes to intense blue. The stamens, borne on short and flattened filaments, have brown elongated anthers bent towards the style, forming a characteristic cone (Fig. 1a). Borage has been cultivated for centuries for wide culinary and medicinal use (Pieszak, Mikołajczak, \& Manikowska, 2012). Its young leaves and flowers are used in salads, soups, vegetable and meat dishes and drinks (Biscotti \& Pieroni, 2015). As a valuable medicinal plant and herb (Gupta \& Singh, 2010; Asadi-Samani et al., 2014), it is mainly grown for borage seed oil, the richest plant source of $y$-linolenic acid (GLA). Borage herb (Boraginis herba) collected during flowering contains mucous compounds, tannins, saponins, flavonoids, phenolic acids, organic acids, scopoletin, soluble silica and mineral salts (Zemmouri et al., 2014). Due to the content of biologically active components, borage is used in the production of the dietary supplements (Pieszak, Mikołajczak, \& Manikowska, 2012). 

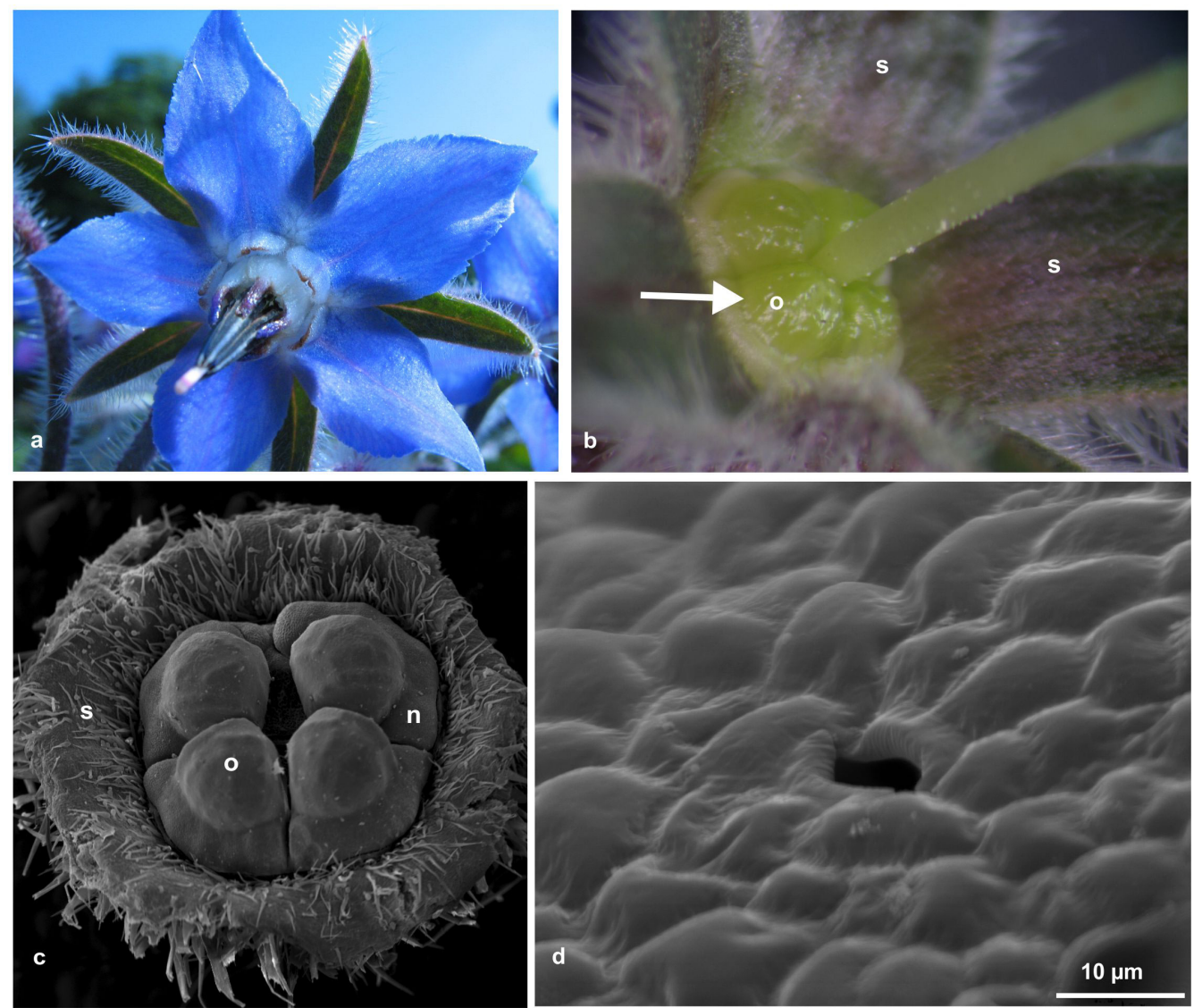

Fig. 1. Morphology and microstructure of a Borago officinalis flower. a. Front view of a flower. b. Fourloculed ovary with a nectary ring below (arrow). c. Four-lobed nectary ring (SEM). d. Nectary epidermis with a nectarostoma (SEM). Abbreviations: s - sepal, o - ovary, n - nectary lobe.

In beekeeping literature, borage is described as a nectariferous plant recommended for cultivation near apiaries (Osborne, 1999). Its flowers attract a diversity of flower-visiting insects, including Hymenoptera, Lepidoptera, and Diptera, but they are foraged mostly by honey bees and bumblebees (Hedtke, 1996; Davis, Mitchell, \& Junor, 1997; Osborne, 1999; Carreck \& Williams, 2002; Carvell et al., 2006; Simmons, Sagili, \& Martens, 2013). Results of pollen analyses of honeys (Ricciardelli D'Albore \& Battaglini, 1971; Sejo et al., 1994; Salonen et al., 2009; Aronne et al., 2012; Kilic, Kutlu, \& Ozdemir, 2016) and pollen loads (Aronne et al., 2012; Salman \& Azzazy, 2013; Dimou et al., 2014) have shown that honey bees are interested in collecting both nectar and pollen from borage flowers. In the UK, borage crops are listed among principal honey flows (Williams, Carreck, \& Little, 1993). It is in described as a source of varietal honeys in Italy, Spain, the Netherlands, Finland, Norway, and Sweden (Persano Oddo et al., 2004). Borage honey is pale, runny and slow to granulate, whereas pollen loads are beige (Hodges, 1984) or creamy-white (Osborne, 1999). According to Demianowicz (1961), unifloral borage honey is creamy-white. The attractiveness of borage flowers to bumblebees was confirmed by pollen analysis of faeces and pollen loads of Bombus terrestris (Teper, 2006; Carvell et al., 2006).

Despite the popularity of borage as a bee plant in western and southern Europe, the data on its forage value in the eastern part of the EU are incomplete. For example, in Poland, some studies of the melliferous value of borage were conducted in the 1960s (Demianowicz et al., 1960; Demianowicz, 1961; Maksymiuk, 1961), and since then, no detailed studies on borage as a forage source for insects have been carried out. However, a steady increase in borage honey production has been noted in Poland (Semkiw et al., 2008). Thus, the main objectives of the present study were to investigate (i) the borage flowering pattern and abundance in the 
environmental conditions prevailing in SE Poland and (ii) to evaluate its attractiveness (in terms of nectar and pollen production) for flower-visiting insects, mainly bees. Since borage is grown as a seed crop, the insect visitation (iii) and the effect of pollinators (iv) on fruit set and seed set were assessed as well. Furthermore, morphological features of borage pollen grains (v) that are useful in palynological studies of bee products were studied.

\section{MATERIAL AND METHODS}

\section{Study site}

The study was conducted in Lublin $\left(51^{\circ} 16^{\prime} \mathrm{N}\right.$, $22^{\circ} 30^{\prime} \mathrm{E}$ ), SE Poland between 2007 and 2009. The study area is characterized by an average annual air temperature of $8.3^{\circ} \mathrm{C}$ and average annual precipitation of $550.6 \mathrm{~mm}$.

Experimental plots sized $6 \mathrm{~m} \times 3 \mathrm{~m}$ were established on grey brown podsolic soil. The plots were fertilised before sowing with Azofoska (Inco S.A., Poland) fertiliser, with the 13:6:17 NPK ratio plus $\mathrm{S}, \mathrm{Ca}$, and microelements. The seeds were sown directly into the soil in the middle of April. The spacing between rows was $60 \mathrm{~cm}$. After emergence, the seedlings were thinned to obtain a ca. $40 \mathrm{~cm}$ distance between plants in a row. The average density of the plants was $5 \cdot \mathrm{m}^{-2}$ plot.

\section{Flowering pattern and abundance}

During the period 2007-2009, the flowering onset and termination were recorded. In 2007, the seasonal flowering pattern was examined as well. To this end, six plants were randomly chosen and marked prior to the opening of the first flowers. On the consecutive days of blooming, the number of open flowers on each plant was counted until blooming terminated. The daily flowering patterns were observed on the $16^{\text {th }}$ and $17^{\text {th }}$ July 2007 at the peak flowering of the species, and the number of newly opened flowers on 8 stems was recorded every two hours from 8:00 to 20:00 (GMT + 2 hrs). Additionally, the total number of flowers developed per plant and per $1 \mathrm{~m}^{2}$ area was determined. The flower life span was observed from the loose bud stage until the petals were shed. These observations were performed on six flowers each year.

\section{Floral nectaries, nectar and pollen production}

The distribution of nectaries in fresh flowers was investigated under an Olympus SZX12 stereoscopic microscope (Tokyo, Japan). Next, the nectaries were prepared for SEM. The flower bases were fixed in $2.5 \%$ glutaraldehyde in phosphate buffer ( $\mathrm{pH} 7.4 ; 0.1 \mathrm{M})$ at $4^{\circ} \mathrm{C}$ for twelve hours. Then, the material was washed in phosphate buffer and dehydrated in a graded acetone series. Afterwards, plant material was critical-point dried using liquid $\mathrm{CO}_{2}$, sputter-coated with gold and examined with TESCAN/VEGA LMU SEM (TESCAN, Brno, Czech Republic) at an accelerating voltage of $30 \mathrm{kV}$.

To quantify the 24-hr rate of nectar secretion, the flower buds were isolated in the field and the accumulated nectar was collected (Corbet, 2003) using Jabłoński' pipettes and weighed (in $\mathrm{mg})$. In total, fifty-three nectar samples were collected during this study. A single sample contained nectar collected from ten flowers. The nectar sugar concentration (\% wt/wt) was measured with the RL-4 refractometer (PZO, Warsaw Poland). Then, the nectar amount and nectar sugar concentration were used to calculate the total sugar amount $(\mathrm{mg})$ secreted in nectar ' flower ${ }^{-1}$ (Jabłoński, 2002).

The pollen amount available to insects was determined with the modified ether method (Warakomska, 1972). Every year, twelve samples were collected, each consisting of fifty mature stamens. The anthers were removed from randomly chosen flower buds and placed on previously tarred watch glasses. The samples werethen placed in an air dryer(SUP-65G Wamed, Poland) at $30^{\circ} \mathrm{C}$. After anthers dehiscence pollen grains were washed from the them with pure ether and subsequently with $70 \%$ ethanol. The empty anthers were removed from the watch glasses. Next, the pollen samples were dried and weighed on a balance (WA 34 PRL T A14 MERA-KFM, Poland), which allowed the calculation of the mass of air-dried pollen. The results were expressed in $\mathrm{mg}$ ' flower' 
Moreover, both the total sugar amount secreted in nectar and the pollen mass ' plant ${ }^{1}$ and $\mathrm{m}^{-2}$ of the crop available to insects were estimated. To this end, plant density $\cdot \mathrm{m}^{-2}$ of a plot and data on the average number of flowers on a plant already formed during a given growing season were used. The pollen grains were mounted in glycerol-gelatine on microscopic slides $(n=10)$. Each slide was prepared from a mixture sample of pollen collected from 120 flowers. Pollen grains dimensions were determined by the measuring of the length of the polar and equatorial axes using a NIKON ECLIPSE E 600 LM at a magnification of $40 \times 15$. At least fifty pollen grains were measured on each slide (Andrejev, 1926).

\section{Insect visits and pollination}

In 2007, the intensity of diurnal insect visits to the borage flowers was monitored. The number of visits was counted for five minutes, three times every two hours, from 8:00 to 20:00 (GMT +2 hrs). Counting was performed in four marked areas; each sized $1 \mathrm{~m}^{2}$, established inside the experimental plot. The procedure was repeated three times during the full bloom of the species in sunny and not windy weather. The observations revealed five insect categories: honey bees, bumblebees, non-Apis and non-Bombus bees, flies (Diptera) and others (butterflies, beetles and thrips). The fruit set and seed set between flowers bagged to exclude insects $(n=399)$ and those freely pollinated $(n=315)$ were compared to determine the role of insects as pollinators of borage crops. The pollination treatments were conducted on eight randomly chosen plants. On each plant, six stems with a similar number of flower buds in the same developmental phase were marked. Then, three stems were bagged in tulle isolators (mesh size $1 \mathrm{~mm}$ ) until flowering cessation, whereas the others stayed unbagged for free pollination. After fruit ripening, the percentage of fruit set in relation to the flowers open on the stems was determined. The seed set was calculated as a percent of the number of seeds harvested from a flower in comparison to the maximum potential number per flower (four seeds per flower). The field pollination experiment was performed in 2007.

\section{Statistical analyses}

All analyses were performed using STATISTICA v.13 (StatSoft, Poland, Kraków). The total number of flowers . plant ${ }^{-1}$ and the total number of flowers $\cdot \mathrm{m}^{-2}$ were tested using Kruskal-Wallis non-parametric ANOVA and $\mathrm{H}$-test. Differences in the nectar amount, nectar sugar concentration, total sugar amount in the nectar and the pollen amount between the years of the study were compared using one-way ANOVAs. When significant differences were found, the ANOVAs were followed by the HSD Tukey test at $p=0.05$. The Chi-square contingency test was applied for the fruit set and the seed set.

\section{RESULTS}

\section{Flowering biology and abundance}

In the climatic conditions of SE Poland, borage blooming started sixty days after sowing in the latter half of June and often lasted until the latter half of August. The detailed dates of the seasonal blooming periods are shown in Table 1. The flowering period on average lasted eight weeks. The time of blooming differed among the years of the study and depended on the weather conditions. Generally, the thermal conditions in all growing seasons were similar and hot weather prevailed - the daily mean temperatures of June, July and August exceeded the multiyear mean values by approx. $1.3^{\circ} \mathrm{C}$. However, the extremely dry weather during the final ten days of June 2007 (total precipitation $3.2 \mathrm{~mm}$ ) accelerated the blooming process in the plants by ten to eleven days, compared to 2008 and 2009.

During the first week of flowering, the flowers on the borage plants developed at a slow rate, but the process intensified in the second week. Peak flowering was recorded in the third and fourth week of blooming. In the fifth week, the number of open flowers steadily decreased and the termination of blooming started in the sixth week (Fig. 2).

The observations of the daily flowering pattern (Fig. 3) showed that the greatest number of flowers opened before 8:00 and between 14:00 and 20:00. The lowest portion of newly opened 


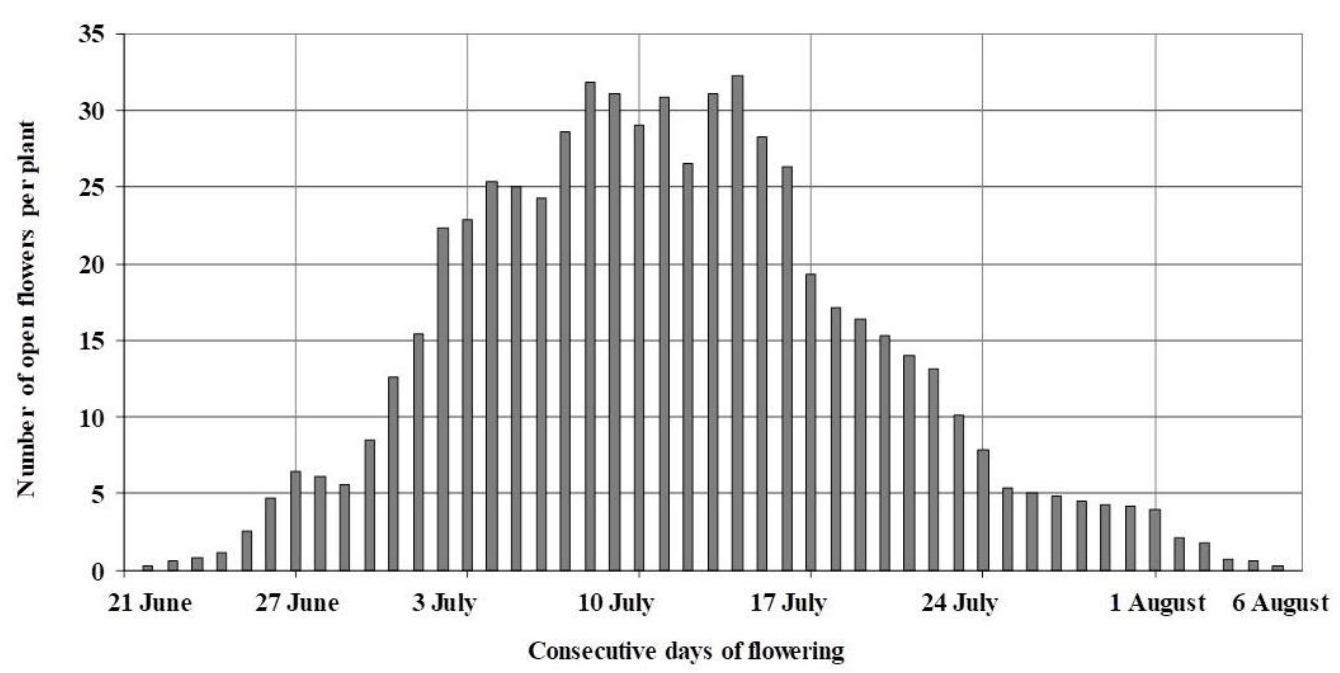

Fig. 2. Seasonal flowering pattern of Borago officinalis plants in 2007. The bars represent mean values $(n=6)$.

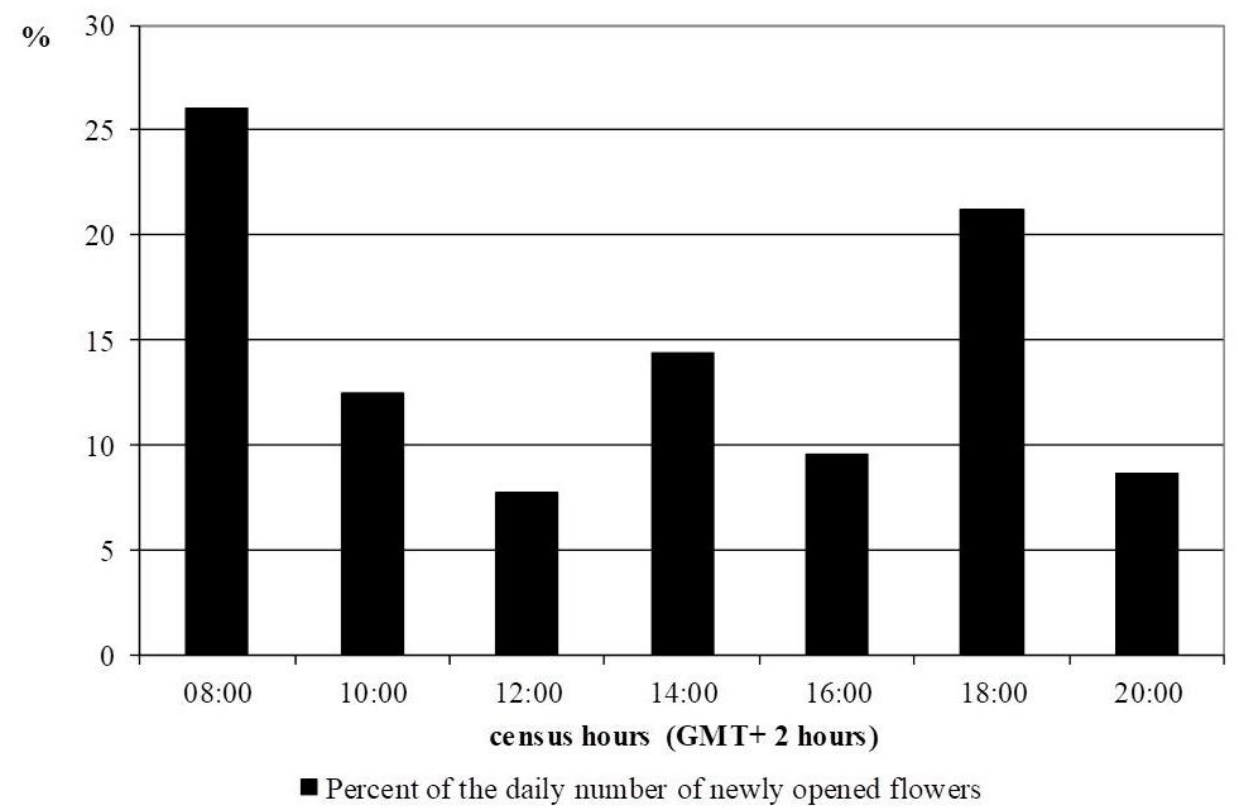

Fig. 3. Daily pattern of opening Borago officinalis flowers per stems $(n=8)$ recorded on the $16^{\text {th }}$ and $17^{\text {th }}$ June 2007. The bars represent mean values.

flowers was noted during noon hours. During the peak flowering of the species, the daily number of all open flowers per plant exceeded thirty (Fig. 2). The detailed data on the blooming abundance of borage are shown in Tab. 1. The effect of the growing season on the number of flowers formed per plant and per area unit was not significant $\left(\mathrm{H}_{2,26}=1.14, \mathrm{p}=0.57\right.$ and $\mathrm{H}_{2,26}=0.67$, $p=0.71)$. The life span of a borage flower, on average 22 hours, was similar in each year of the study $\left(\mathrm{H}_{2,18}=1.62, \mathrm{p}=0.45\right)($ Tab. 1).

\section{Nectaries and nectar production}

Nectar in a borage flower is produced by an irregular four-lobed nectary ring located at the base of the ovary (Fig. 1bc). The nectary is surrounded by thickened bases of filaments. Five apertures formed in the non-thickened part of the filament base lead to the nectar, and the throat scales in the corolla are located opposite these holes. Nectar is released through nectarostomata in the nectary epidermis (Fig. 1d). The nectar secretion begins at the loose bud stage and lasts throughout the entire life of the flower. 
Table 1.

Flowering phenology and abundance of Borago officinalis L. in the years of study.

Mean values ( \pm SD) are given, SD - standard deviation. The results for life span of the flower, number of flowers ' plant ${ }^{1}$ and number of flowers $\cdot \mathrm{m}^{-2}$ of plot do not significantly differ between years of study $(p>0.05)$.

\begin{tabular}{|c|c|c|c|c|}
\hline \multirow{2}{*}{ Year } & \multirow{2}{*}{$\begin{array}{l}\text { Flowering time } \\
\text { (days) }\end{array}$} & \multirow{2}{*}{$\begin{array}{l}\text { Life span } \\
\text { of a flower } \\
\text { (hours) }\end{array}$} & \multicolumn{2}{|c|}{ Number of flowers } \\
\hline & & & plant $^{-1}$ & $\mathrm{~m}^{-2}$ of plot \\
\hline 2007 & $\begin{array}{c}20.06-07.08 \\
(49)\end{array}$ & $\begin{array}{c}21.3 \pm 1.15 \\
n=6\end{array}$ & $\begin{array}{c}1024 \pm 628 \\
n=6\end{array}$ & $\begin{array}{c}4866 \pm 2981 \\
n=6\end{array}$ \\
\hline 2008 & $\begin{array}{c}17.06-14.08 \\
\text { (59) }\end{array}$ & $\begin{array}{c}20.6 \pm 1.53 \\
n=6\end{array}$ & $\begin{array}{c}999 \pm 365 \\
n=10\end{array}$ & $\begin{array}{c}4744 \pm 1731 \\
n=10\end{array}$ \\
\hline 2009 & $\begin{array}{c}22.06-20.08 \\
(60)\end{array}$ & $\begin{array}{c}21.7 \pm 2.08 \\
n=6\end{array}$ & $\begin{array}{c}863 \pm 332 \\
n=10\end{array}$ & $\begin{array}{c}4100 \pm 1578 \\
n=10\end{array}$ \\
\hline mean & (56) & $\begin{array}{c}21.2 \pm 1.00 \\
n=18\end{array}$ & $\begin{array}{c}953 \pm 414 \\
n=26\end{array}$ & $\begin{array}{c}4570 \pm 1968 \\
n=26\end{array}$ \\
\hline
\end{tabular}

Table 2.

Nectar production parameters in Borago officinalis L. in the growing seasons 2007-2009. Mean values ( \pm SD) are given, SD - standard deviation. The results for all nectar parameters do not significantly differ among the years of the study $(p>0.05)$.

\begin{tabular}{|c|c|c|c|c|c|}
\hline \multirow[b]{2}{*}{ Үеаг } & \multicolumn{2}{|c|}{ Amount $\cdot$ flower ${ }^{1}$ of: } & \multirow{2}{*}{$\begin{array}{c}\text { Sugar concentration } \\
\text { of nectar } \\
\text { (\% wt/wt) }\end{array}$} & \multicolumn{2}{|c|}{$\begin{array}{l}\text { Amount of sugars secreted } \\
\text { in nectar: }\end{array}$} \\
\hline & $\begin{array}{l}\text { nectar } \\
\text { (mg) }\end{array}$ & $\begin{array}{c}\text { sugars } \\
\text { secreted in } \\
\text { nectar (mg) }\end{array}$ & & plant $^{-1}$ (g) & $\mathrm{m}^{-2}$ of crop (g) \\
\hline 2007 & $\begin{array}{c}4.3 \pm 2.4 \\
n=20\end{array}$ & $\begin{array}{c}0.9 \pm 0.2 \\
n=20\end{array}$ & $\begin{array}{c}26.7 \pm 10.9 \\
n=20\end{array}$ & $\begin{array}{c}1.0 \pm 0.6 \\
n=6\end{array}$ & $\begin{array}{c}4.5 \pm 1.2 \\
n=20\end{array}$ \\
\hline 2008 & $\begin{array}{c}4.0 \pm 2.2 \\
n=14\end{array}$ & $\begin{array}{c}1.3 \pm 0.6 \\
n=14\end{array}$ & $\begin{array}{c}36.3 \pm 18.8 \\
n=14\end{array}$ & $\begin{array}{c}1.3 \pm 0.5 \\
n=10\end{array}$ & $\begin{array}{c}6.3 \pm 3.0 \\
n=14\end{array}$ \\
\hline 2009 & $\begin{array}{c}3.8 \pm 2.2 \\
n=19\end{array}$ & $\begin{array}{c}1.3 \pm 0.6 \\
n=19\end{array}$ & $\begin{array}{c}33.8 \pm 4.9 \\
n=19\end{array}$ & $\begin{array}{c}1.1 \pm 0.4 \\
n=10\end{array}$ & $\begin{array}{c}5.1 \pm 2.5 \\
n=19\end{array}$ \\
\hline mean & $\begin{array}{c}4.0 \pm 2.2 \\
n=53\end{array}$ & $\begin{array}{c}1.2 \pm 0.5 \\
n=53\end{array}$ & $\begin{array}{c}31.5 \pm 13.1 \\
n=53\end{array}$ & $\begin{array}{c}1.1 \pm 0.5 \\
n=26\end{array}$ & $\begin{array}{c}5.2 \pm 2.3 \\
n=53\end{array}$ \\
\hline
\end{tabular}

The characteristics of nectar produced by borage flowers in consecutive growing seasons are shown in Tab. 2. All the parameters, i.e. nectar amount, nectar sugar concentration and nectar sugar amount varied among the years of the study (although not statistically; $F_{2,50}=$ $0.21, p=0.81 ; F_{2,45}=2.68, p=0.80$, and $F_{2,50}^{2,50}=$ 2.92, $p=0.06$, respectively).
Nectar amount $\cdot$ flower $^{-1}$ was on average 4.0 $\pm 2.2 \mathrm{mg}(n=53)$. The nectar sugar concentration was moderate but ranged widely from 10 to $66 \%$. The mean sugar amount secreted in nectar ' flower $^{-1}$ was $1.2 \pm 0.5 \mathrm{mg}(n=53)$. The estimated production of nectar sugars per plant and per $1 \mathrm{~m}^{2}$ of the crop showed no year effect $\left(F_{2,23}=1.22, p=0.31\right.$ and $F_{2,50}=2.34$, $p=0.11$, respectively). Throughout the growing 
Table 3.

Pollen production in Borago officinalis during growing seasons 2007-2009.

Mean values ( \pm SD) are given, SD - standard deviation.

\begin{tabular}{|c|c|c|c|}
\hline \multirow{2}{*}{ Year } & \multicolumn{3}{|c|}{ Pollen amount: } \\
\hline & flower $^{-1}(\mathrm{mg})$ & plant $^{-1}(\mathrm{~g})$ & $\mathrm{m}^{-2}$ of crop (g) \\
\hline 2007 & $\begin{array}{c}1.3^{\mathrm{a}} \pm 0.5 \\
\mathrm{n}=12\end{array}$ & $\begin{array}{c}1.4^{\mathrm{a}} \pm 0.8 \\
n=6\end{array}$ & $\begin{array}{c}6.4^{\mathrm{a}} \pm 2.6 \\
n=12\end{array}$ \\
\hline 2008 & $\begin{array}{c}1.1^{b} \pm 0.2 \\
n=12\end{array}$ & $\begin{array}{c}1.1^{\mathrm{a}} \pm 0.4 \\
\mathrm{n}=10\end{array}$ & $\begin{array}{c}5.1^{\mathrm{a}} \pm 1.2 \\
\mathrm{n}=12\end{array}$ \\
\hline 2009 & $\begin{array}{c}1.0^{\mathrm{b}} \pm 0.4 \\
\mathrm{n}=12\end{array}$ & $\begin{array}{c}0.9^{a} \pm 0.3 \\
n=20\end{array}$ & $\begin{array}{c}4.2^{\mathrm{b}} \pm 1.5 \\
\mathrm{n}=12\end{array}$ \\
\hline mean & $\begin{array}{c}1.1 \pm 0.4 \\
n=36\end{array}$ & $\begin{array}{c}1.1 \pm 0.5 \\
n=26\end{array}$ & $\begin{array}{c}5.2 \pm 2.0 \\
n=36\end{array}$ \\
\hline
\end{tabular}

Means in columns with the same letters do not differ significantly; the HSD Tukey test, $p=0.05$

season, on average $1.1 \pm 0.5 \mathrm{~g}(n=26)$ of sugars could be collected by insects from one borage plant. The estimated mean nectar sugar yield . $\mathrm{m}^{-2}$ of this crop was $5.21 \pm 2.34 \mathrm{~g}(\mathrm{n}=53)$, i.e., $52.1 \mathrm{~kg} \cdot \mathrm{ha}^{-1}$.

\section{Pollen release and production}

Borage flowers are protandrous. Mature anthers open towards the inside of a conical staminal tube consisting of tightly packed anther heads where pollen grains are released and accumulated. When the anthers are empty, the style extends and protrudes beyond the anthers, while the stigma is getting receptive (Fig. 1a).

The amounts of pollen ' flower $^{-1}$ differed significantly among the years of the study $\left(F_{2^{\prime} 30}=\right.$ $14.77, p=0.00)$. The highest average value of 1.3 \pm 0.5 ( $n=12) \mathrm{mg}$ per flower was found in 2007 , whereas the values for the following years of study were $15-23 \%$ lower (Tab. 3). The estimated pollen amount $\cdot$ plant $^{-1}$ showed no effect of the year $\left(F_{2,23}=1.65, p=0.22\right)$, whereas the pollen amount $\cdot 1 \mathrm{~m}^{-2}$ of the crop differed significantly among the years of the study $\left(F_{2, з 3}=4.61\right.$, $P$ $=0.02$ ). During the growing season, one borage plant provided $1.1 \pm 0.5 \mathrm{~g}(n=52)$ of pollen, i.e. $5.21 \pm 2.01 \mathrm{~g}(\mathrm{n}=36) \cdot \mathrm{m}^{-2}$ of the crop.

Borage pollen grains are stephanocolporate (Fig. 4) with the average length of the polar axis $(P)$ of $33.5 \mathrm{~mm}$ (range $30.3-38.7 \mathrm{~mm}$ ) and that of the equatorial axis $(E)$ of 34.0 mm (range 31.3-39.2 $\mathrm{mm})$. The shape index (P/E) is 0.99 .

Insect visitation and pollination

Hymenopterans were the principal visitors to the borage flowers (Fig. 5). Their visits accounted for $73 \%$ of all insect visits observed. Honey bees dominated among them, but bumblebees as well as non-Apis and non-Bombus bees were similarly abundant (Fig. 5). The flowers were visited by a number of dipterans as well. Bees collected both nectar and pollen from the flowers (Fig. 6). Microscopic analysis of grey-beige corbicular pollen loads of honey bees and bumblebees confirmed the presence of numerous borage pollen grains (unpublished data).

Insects foraged on the flowers from early morning to evening (Fig. 7). The most intense visitation was observed between 10:00 and 14:00 when the majority of new flowers were open, providing nectar and pollen.

The presence of insects significantly increased both the fruit set and the seed set in borage ( $\chi^{2}$ test, $d f=1, p<0.00$ in both cases). In freely pollinated flowers, the percent fruit set was $45.1 \%$ ( $n=315$ ) whereas it was $1.8 \%$ ( $n=399$ ) when pollinators were excluded. The seed set reached $27.9 \%(n=1596)$ in the freely pollinated plants and only $1.1 \%(n=1260)$ in inflorescences bagged to prevent insect access. 

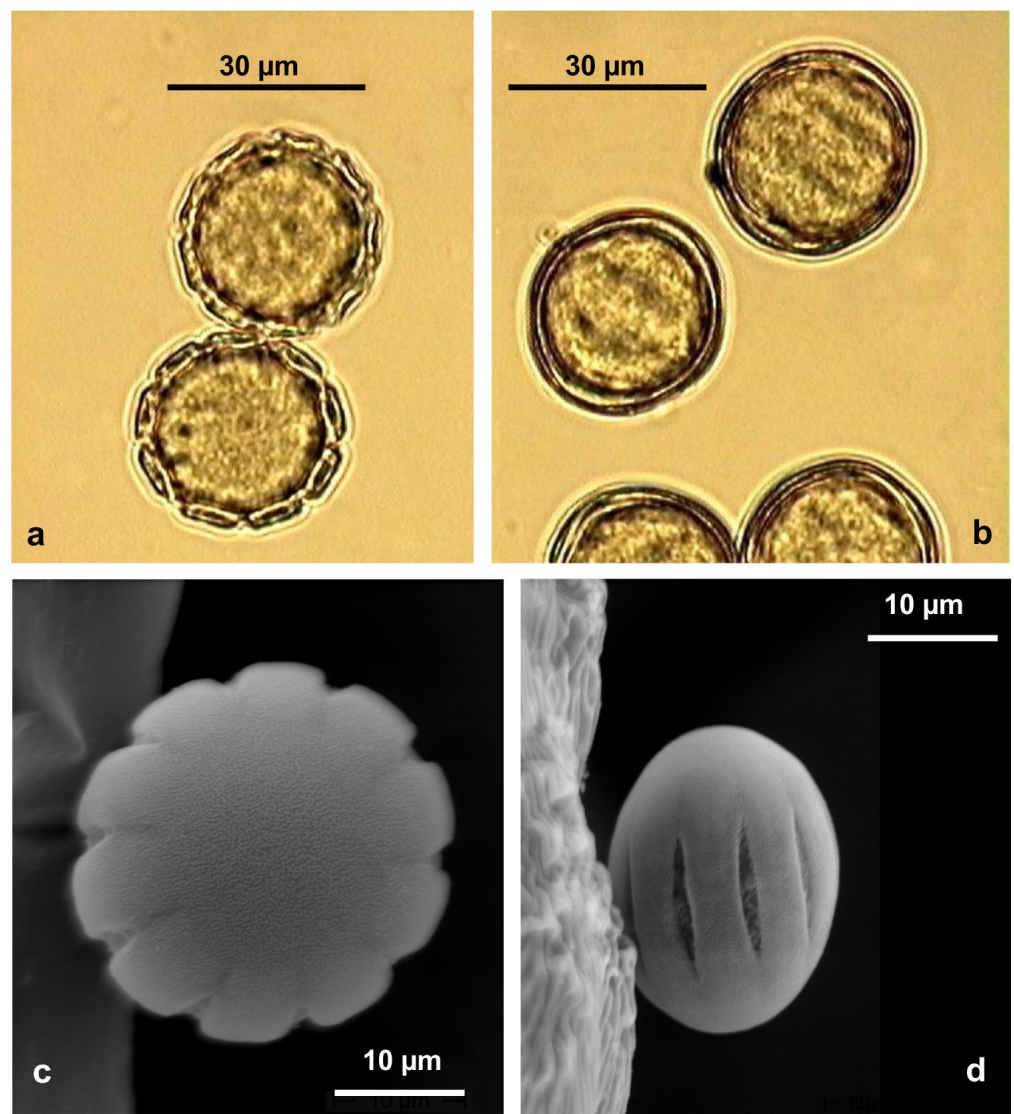

Fig. 4. Micrographs of Borago officinalis pollen grains. a. Polar view, LM. b. Equatorial view, LM. c. Polar view, SEM. d. Equatorial view, SEM.

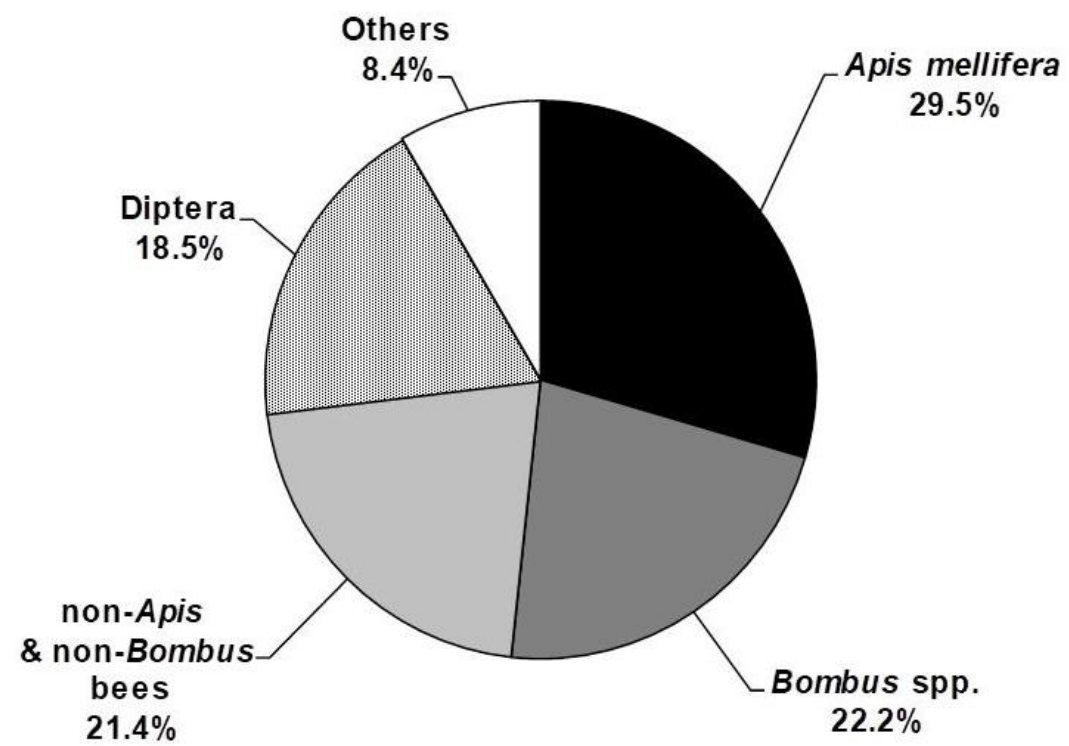

Fig. 5. Insect visits expressed as the percentage of total visits to Borago officinalis flowers recorded in 2007 and diurnal visitors to flowers. 

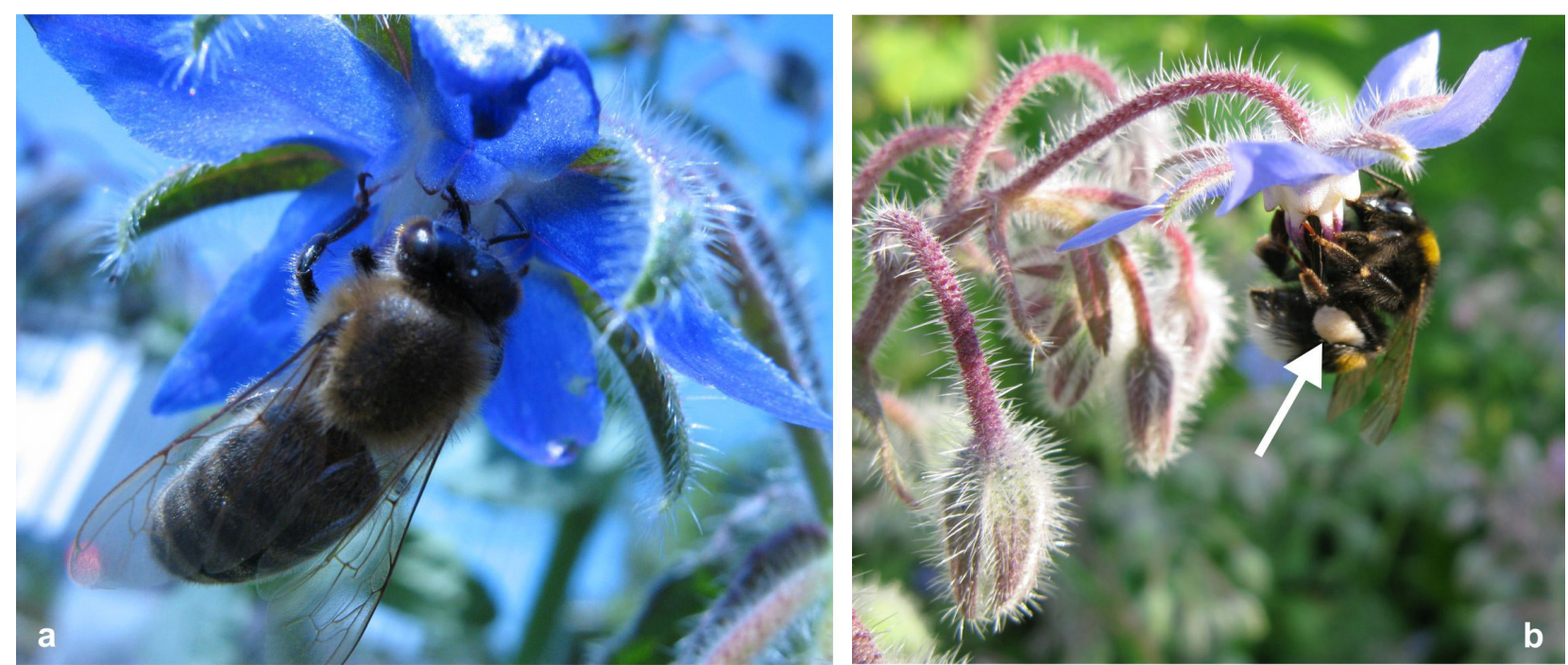

Fig. 6. Bees foraging on Borago officinalis flowers. a. Honey bee gathering nectar. b. Bumblebee collecting nectar and pollen with a visible corbicular pollen load (arrow).

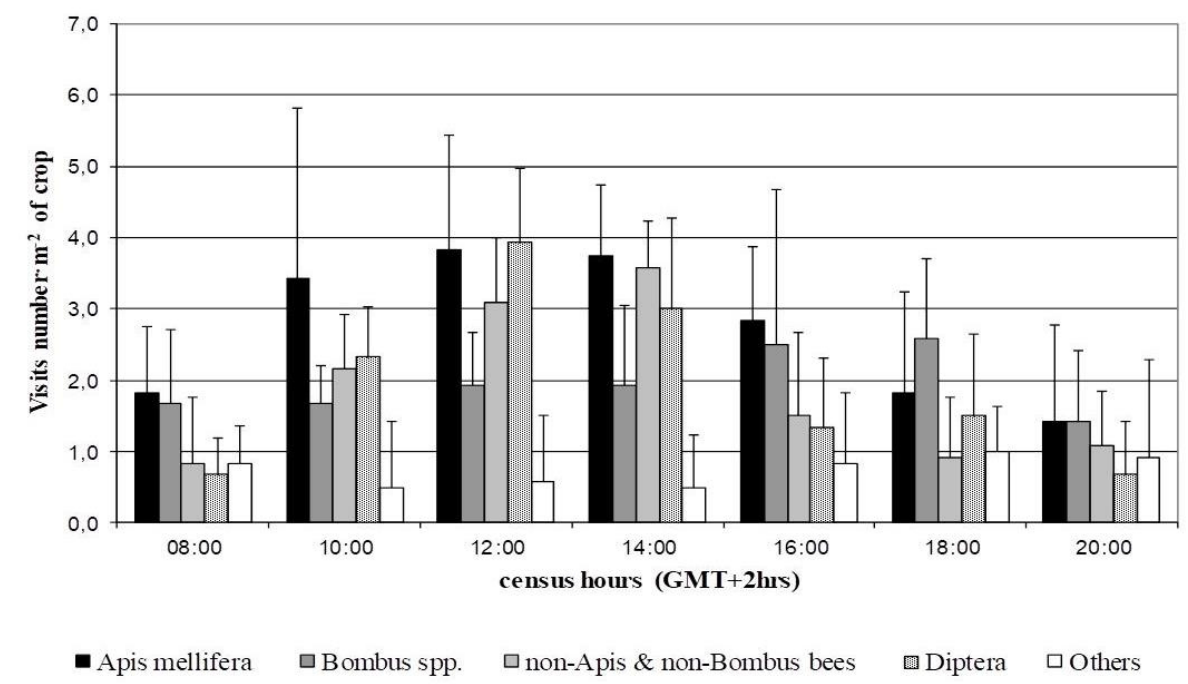

Fig. 7. Number of insect visits (mean and SD) to Borago officinalis crops throughout the day in the 2007 season ( $n=252$ records).

\section{DISCUSSION}

In the conditions of SE Poland, borage is a longflowering summer crop blooming from June to late August, which coincides with the period of the foraging activity of many bees. Borage can bloom from April to October depending on the sowing date and geographical location (Osborne, 1999; Decourtye, Mader, \& Desneux, 2010; Simmons, Sagili, \& Martens, 2013). In Lublin, the flowering of the plants lasts eight weeks, which is twice longer than it was reported for the same region by Kołtowski (2006). In East Europe, borage blooms even up to 11.5 weeks
(Głuchov, 1974). The long flowering of borage crops is an advantageous trait, useful for the long seasonal cycle of bumble bee and honey bee colonies (Osborne, 1999).

Borage is a mass-flowering crop with a mean of 4570 flowers $\cdot \mathrm{m}^{-2}$ developed during the growing season. This abundance is similar to that reported by Demianowicz et al. (1960) but almost twofold lower than the data provided by Maksymiuk (1961) - 7428 flowers $\cdot \mathrm{m}^{-2}$ of borage crop. Our study shows that borage in SE Poland was most attractive to the flower-visiting insects in the second and third week of flowering when it reached the peak floral display. 
Borage flowers persist for twenty-two hours on average and produce nectar during their entire life. Nectar is secreted by a four-lobed nectary ring located at the base of the ovary and released via nectarostomata. Similar localization and morphology of floral nectaries and the mode of nectar release were found in the other species from the Boraginaceae family, e.g., Symphytum officinale (Stpiczyńska, 2003) and Echium russicum (Chwil \& Weryszko-Chmielewska, 2007).

Borage offers an ample nectar reward to insect visitors. The nectar sugar amount $\cdot$ flower $^{1}$ $(1.2 \mathrm{mg})$ was similar to that reported previously (1.1 $\mathrm{mg} \cdot$ flower $^{-1}$ ) in Poland (Demianowicz et al., 1960; Maksymiuk, 1961) and within ranges (0.2-4.9 mg ' flower ${ }^{-1}$ ) found in the US crops (Thom et al., 2016 and references herein). Our results show that one borage flower can provide more nectar sugars than a single flower of winter rape (0.95-1.07 mg) (Kołtowski, 2002) or white mustard $(0.25 \mathrm{mg})$ (Masierowska, 2003), which are important honey crops grown in the environmental conditions of SE Poland. The estimated sugar yield of $52.1 \mathrm{~kg} \cdot \mathrm{ha}^{-1}$ also indicates that borage is a good value crop in terms of nectar production. However, this value is much lower than the estimated sugar yield in winter rape $90-120 \mathrm{~kg} \cdot \mathrm{ha}^{-1}$ or white mustard $-71.2 \mathrm{~kg} \cdot \mathrm{ha}^{-1}$, mainly due to the less abundant flowering of borage plants.

Regardless of the year of the study, borage nectar was moderately concentrated although the values ranged from $10-66 \%$. Previous studies on borage nectar showed a significant variability of this trait from 19-77\% (Demianowicz et al., 1960; Głuchov, 1974; Osborne, 1999). Such nectar offers an energetic reward for such various nectar-consumers as flies and short- and long-tongued bees (Willmer, 2011). Indeed, both hymenopterans and dipterans were important visitors to borage flowers in our field study.

Borage flowers provide pollen food for insects as well. To our knowledge, the pollen output of borage has not been investigated yet, and only a few studies have given evidence that honey bees and bumblebees actively collect borage pollen (Osborne, 1999; Teper, 2006; Aronne et al., 2012). As demonstrated by Ricciardelli D'Albore (1998), the pollen harvest from borage is small, which has been confirmed in our study $\left(1.1 \mathrm{mg} \cdot\right.$ flower $\left.^{1}\right)$. The estimated pollen yield per crop area unit $\left(5.2 \mathrm{~g} \cdot \mathrm{m}^{-2}\right.$, i.e., $\left.52 \mathrm{~kg} \cdot \mathrm{ha}^{-1}\right)$ is comparable with the lowest pollen yield of white mustard crops (53 kg · ha-1) (Masierowska, 2012), a valuable pollen source for bees in Poland. However, borage crops can improve pollen flow and thus honey bee nutrition in late summer, when a natural decline in the availability of pollen occurs. For example, the use of borage as a supplemental source of pollen in late summer cropping systems was proposed in the UK (Carreck \& Williams, 2002) and the USA (Simmons, Sagili, \& Martens, 2013).

The honey bees observed in the borage flowers primarily exploited the nectar and less readily the pollen, which is in accordance with results of the previous studies (Davis, Mitchell, \& Junor, 1997; Teper, 2006; Salonen et. al., 2009; Simmons, Sagili, \& Martens, 2013; Dimou et al., 2014; Kilic, Kutlu, \& Ozdemir, 2016). Bumblebees and honey bees in minority formed grey-beige corbicular pollen loads, in which the presence of the borage pollen was confirmed. Bombus terrestris and B. lucorum, in particular, are known to collect borage pollen (Osborne, 1999; Teper, 2006; Carvell et al., 2006).

Wild and domesticated bees most frequently visited borage flowers in Lublin, with dominance of honey bees. Our observations are in agreement with studies conducted in southern and western Europe (Hedtke, 1996; Carreck \& Williams, 2002; Carvell et al., 2006; Barbir et al., 2015) and confirm the apiarian value of borage crops in various geographical regions. Moreover, a considerable number of dipterans were noted, unlike in the study conducted by Barbir et al. (2015), who demonstrated low attractiveness of borage to hoverflies (Diptera, Syrphidae). Carreck and Williams (2002) reported low diversity of dipterans in borage combined with a moderate abundance of their visits (15\%). In general, the daily pattern of insect visitation to borage flowers can be linked to the daily pattern of opening of new flowers on the plant and thus the availability of food resources. 
Borage benefits from the presence of insects significantly increasing both fruit set and seed set. The plant species is considered self-compatible but its flowers are protandrous to avoid self-pollination (Montaner, Floris, \& Alvarez, 2000). Thus, a biotic pollen vector is necessary to achieve full reproductive success. The need for insects, in particular honey bees, for borage pollination has been documented so far by Davis, Mitchell and Junor (1997) and Gorenflo et al. (2017), who both attributed the effectiveness of pollination by honey bees to their highest visitation frequencies. The pollination effectiveness of different borage pollinators in Polish conditions needs further more detailed studies. In conclusion, our study has demonstrated that borage in the environmental conditions of SE Poland is a valuable nectar and pollen sources during the summer period. Borage flowers produce abundant amounts of sugar in their nectar and provide a great nectar resource for pollinators from various taxonomic groups, including honey bees. Moreover, borage can be a supplemental pollen source and improve bee nutrition in late summer. The forage value of the borage crop is the highest in the second and third weeks of flowering when plants reach the peak floral display.

Borage is strongly dependent on pollinators and their presence decisively impacts seed yield. As honey bees are predominant visitors to borage flowers, their presence should be promoted, in particular, in seed crops. Finally, we recommend a wider use of borage in the agricultural landscape of Poland.

\section{ACKNOWLEDGMENTS}

This research was supported financially by the Ministry of Science and Higher Education of Poland as part of statutory activities of the Department of Botany and Plant Physiology (project OKB/DS/1), University of Life Sciences in Lublin.

\section{REFERENCES}

Andrejev, V.N. (1926). Pylca rastenij soberajemaja pčolami (k metodike izučenija pergi). Charkov. Oblat. Opyt. Stancja, Charkov.

Aronne, G., Giovanetti, M., Guarracino, M.R., \& de Mikko, V. (2012). Foraging rules of flower selection applied by colonies of Apis mellifera. ranking and associations of floral sources. Functional Ecology, 26(5), 1186-1196. http://doi.org/10.1111/j.13652435.2012.02017.x

Asadi-Samani, M., Bahmani, M., \& Rafieian-Kopaei, M. (2014). The chemical composition, botanical characteristic and biological activities of Borago officinalis. a review. Asian Pacific Journal of Tropical Medicine, 7, 22-28. DOl: 10.1016/S1995-7645(14)60199-1

Barbir, J., Badenes-Pérez, F.R., Fernández-Quintanilla, C., \& Dorado, J. (2015). The attractiveness of flowering herbaceous plants to bees (Hymenoptera: Apoidea) and hoverflies (Diptera: Syrphidae) in agroecosystems of Central Spain. Agricultural and Forest Entomology, 171), 20-28. http://doi.org/10.1111/ afe.12076

Biscotti, N., \& Pieroni, A. (2015). The hidden Mediterranean diet: wild vegetables traditionally gathered and consumed in the Gargano area, Apulia, SE Italy. Acta Societatis Botanicorum Poloniae, 84(3), 327338.

Carreck,N.L,\& \& Williams, I.H. (2002).Food for insectpollinators on farmland: insect visits to flowers of annual seed mixtures. Journal of Insect Conservation, 6(1), 13-23. http://doi.org/10.1023/A:1015764925536

Carvell, C., Westrich, P., Meek, W.R., Pywell, R.F., Nowakowski, M. (2006). Assessing the value of annual and perennial forage mixtures for bumblebees by direct observation and pollen analysis. Apidologie, 373), 326-340. http://doi.org/10.1051/apido:2006002

Chwil, M., \& Weryszko-Chmielewska, E. (2007). Nectary structure and nectar secretion of Echium russicum J. F. Gmel. flowers. Acta Agrobotanica, 601), 25-33.

Corbet, S. (2003). Nectar sugar content: estimating standing crop and nectar secretion in the field. Apid- 
ologie, 34(1), 1-10. https://doi.org/10.1051/apido

Davis, A.R., Mitchell, S., \& Junor, D. (1997). The importance of honey bees (Apis mellifera L.) as pollinators of borage (Borago officinalis L.) in Saskatchewan. http://www.usask.ca/soilsncrops/conference-proceedings/previous_years/Files/97/1997docs/364. pdf

Decourtye, A., Mader, E., \& Desneux, N. (2010). Landscape enhancement of floral resources for honey bees in agro-ecosystems. Apidologie, 47(3), 264277. https://doi.org/10.1051/apido/2010024

Demianowicz, Z., Hłyń, M., Jabłoński, B., Maksymiuk, I., Podgórska, J., Ruszkowska, B., Szklanowska, K., Zimna, J. (1960). Wydajność miodowa ważniejszych roślin miododajnych w warunkach Polski. Część I. Pszczelnicze Zeszyty Naukowe, 4(2), 87-104.

Demianowicz, Z. (1961). Pollenkoeffizienten als Grundlage der Guantitativen Pollenanalyse des Honigs. Pszczelnicze Zeszyty Naukowe, 5(2), 95-105.

Dimou, M., Tananaki, Ch., Liolios, V., \& Thrasyvoulou, A. (2014). Pollen foraging by honeybees (Apis mellifera L.) in Greece: botanical and geographical origin. Journal of Apicultural Science, 58(2), 10-23. https:/l doi.org/10.2478/jas-2014-0018

Głuchov, M.M. (1974). Miedonosnyje rastenija. Kołoc, Moskva.

Gorenflo, A., Diekötter, T., van Kleunen, M., Wolters, V., Jauker, F. (2017). Contrasting pollination efficiency and effectiveness among flower visitors of Malva sylvestris, Borago officinalis and Onobrychis viciifolia. Journal of Pollination Ecology, 27(1), 62-70.

Gupta, M., \& Singh, S. (2010). Borago officinalis Linn. an important medicinal plant of Mediterranean region: a review. International Journal of Pharmaceutical Sciences Review and Research, 5(1), 27-34.

Hodges, D. (1984). The pollen loads of the honeybee. IBRA, London.

Hedtke, C. (1996). The attractiveness of 5 culti- vated crops to bees and a mixture of annual plants for flower visiting insect. Pszczelnicze Zeszyty Naukowe, 40(2), 219-225.

Jabłoński, B. (2002). Notes on the method to investigate nectar secretion rate in flowers. Journal of Apicultural Science, 46(2), 117-125.

Kilic, O., Kutlu, M.A., \& Ozdemir, F.A. (2016). Pollen analysis of honey from the Hizan District of Bitlis Province, eastern region of Turkey. International Journal of Plant, Animal and Environmental Sciences, 6(1), 321-331.

Kołtowski, Z. (2002). Beekeeping value of recently cultivated winter rapeseed cultivars. Journal of Apicultural Science, 46(2), 23-33.

Kołtowski, Z. (2006). Wielki atlas roślin miododajnych. Przedsiębiorstwo Wydawnicze Rzeczpospolita SA, Warszawa.

Maksymiuk, l. (1961). Ogórecznik lekarski - bogate źródło pożytku. Pszczelarstwo, 12(3), 14-15.

Masierowska, M.L. (2003). Floral nectaries and nectar production in brown mustard (Brassica juncea) and white mustard (Sinapis alba)(Brassicaceae). Plant Systematics and Evolution, 238(7-4), 97-107.

Masierowska, M. (2012). Floral display and reproductive system in brown mustard Brassica juncea (L.) Czern. et Coss. and white mustard Sinapis alba L., Brassicaceae. Wydawnictwo Uniwersytetu Przyrodniczego w Lublinie.

Montaner, C., Floris, E., \& Alvarez, J.M. (2000). Is self-compatibility the main breeding system in borage (Borago officinalis L.)? Theoretical and Applied Genetics, 107(1-2), 185-189. https://doi.org/10.1007/ s001220051467

Osborne, J.L. (1999). Borage. Bee World, 801), 33-36. https://doi. org/10.1080/0005772X.1999.11099417

Persano Oddo, L., Piana, L., Bogdanom, S., Bentabol, A., Gotsiou, P., Kerkvliet, J., ... Ohe von der, K. (2004). Botanical species giving unifloral honey in Europe. 


\section{J. APIC. SOLI. VOL. 64 NO. 1 2020}

Apidologie, 35, 82-93. https://doi.org/10.1051/apido:2004045

Pieszak, M., Mikołajczak, P.t., \& Manikowska, K. (2012). Borage (Borago officinalis L.) - a valuable medicinal plant used in herbal medicine. Herba Polonica, 58(4), 95-103.

Ricciardelli D'Albore, G., \& Battaglini, M. (1971). Lo spettro pollinico di alcuni mieli della Sicilia. Annals Faculty Agriculture Universita Perugia, 26, 275-303.

Ricciardelli d'Albore, G. (1998). Mediterranean melissopalynology. Universita degli studi di Perugia, Istituto di Entomologia agraria, Perugia.

Salman, A.A., \& Azzazy, M.F. (2013). Determination of honey floral sources using pollen grains. Journal of Jazan University 2 - Applied Sciences Branch, Z(2), 45-57.

Salonen, A., Ollikka, T., Grönlund, E., Ruottinen, L., JuIkunen-Tiitto, R. (2009). Pollen analyses of honey from Finland. Grana, 48(4), 281-289, http://dx.doi. org/10.1080/00173130903363550

Sejo, M.C., Jato, M.V., Aria, M.J., \& Iglesias, M.I. (1994). Caratterizzazione pollinica dei mieli di Lugo (N.O. Spagna). Apicoltura, 9, 7-18.

Semkiw, P., Skowronek, W., Teper, D., \& Skubida, P. (2008). Changes occurring in honey during ripening under controlled conditions based on pollen analysis and electrical conductivity. Journal of Apicultural Science, 52(2), 45-56.

Simmons, R., Sagili, R., \& Martens, B. (2013). Flower Species as a Supplemental Source of Pollen for Honey Bees (Apis mellifera) in Late Summer Cropping Systems. Central Oregon Agricultural Research Center, Madras Oregon. Series/Report number: COARC2013.

Suchorska, K., \& Osińska, E. (1997). Some aspects of borage (Borago officinalis L.) cultivation. Part I. Influence of temperature, age of seeds and type of bed on germination and growth of seedlings. Annals of
Warsaw Agricultural University - ScGW, Horticulture 18,75-80.

Stpiczyńska, M. (2003). Sekrecja nektaru w kwiatach żywokostu lekarskiego (Symphytum officinale L.) i jego skład chemiczny. Acta Agrobotanica, 56(1-2), 27-37.

Szafer, W., Kulczyński, S., \& Pawłowski, B. (1988). Rośliny polskie. PWN, Warszawa.

Teper, D. (2006). Food plants of Bombus terrestris L. as determined by pollen analysis of faeces. Journal of Apicultural Science, 502), 101-108.

Thom, M.D., Eberle, C.A., Forcella, F., Gesch, R., Weyers, S., Lundgren, J.G. (2016). Nectar production in oilseeds: food for pollinators in an agricultural landscape. Crop Science, 56(2), 727-739. http//doi. org/10.2135/cropsci2015.05.0322

Trzaskowska, E. (2013). Plants species identified in front gardens of town's housing estates. Acta Scientiarum Polonorum, Hortorum Cultus, 12(1), 13-25.

Warakomska, Z. (1972). Badania nad wydajnością pyłkową roślin. Pszczelnicze Zeszyty Naukowe, 16, 63-90.

Williams, I.H., Carreck, N., \& Little, D.J. (1993). Nectar sources for honey bees and the movement of honey bee colonies for crop pollination and honey production in England. Bee World, 74(4), 160-175. https://doi.org/10.1080/0005772X.1993.11099182

Willmer, P. (2011). Pollination and floral ecology. Princeton University Press.

Zemmouri, H., Ammar, S., Boumendjel, A., Messarah, M., El Feki, A., Bouaziz, M. (2014). Chemical composition and antioxidant activity of Borago officinalis L. leaf extract growing in Algeria. Arabian Journal of Chemistry. XXX, 1-10. https://doi.org/10.1016/j. arabjc.2014.11.059 